\title{
Advanced Decomposition of Coking Wastewater in Relation to Total Organic Carbon Using an Electrochemical System
}

\author{
Hao Wang**, Bingxu Quan¹, Xiaoqing An¹, Yang Yang1, Can Tian ${ }^{1,2}$ \\ ${ }^{1}$ College of Civil and Architectural Engineering, North China University of Science and Technology, \\ Tangshan, 063009, P.R. China \\ ${ }^{2}$ Drainage Engineering Technology Research Center of Tangshan City, \\ Tangshan, 063009, P.R. China
}

Received: 4 August 2016

Accepted: 26 September 2016

\begin{abstract}
This research included experiments on the advanced treatment of coking wastewater by electrochemical reactor. The results showed that a favorable operating condition could be obtained through the electrochemical course, when electrolysis time was $60 \mathrm{~min}$, current density was $8 \mathrm{~A}$, and electrode span was $1 \mathrm{~cm}$. Under this condition, total organic carbon (TOC) removal efficiency could reach $73 \%$, and the removal mechanism had also been analyzed. In addition, the electrodes' morphology characteristics and components were analyzed through a scanning electron microscope, and the results showed that on the surface of anode and cathode electrodes there were quite a few cracks, the amount of which increased after use. Meanwhile, the content of chemical elements on the electrodes' surface changed obviously after use - especially Ti content (from $39.66 \%$ to $92.69 \%$ ) on the anode and Fe content (from $72.57 \%$ to $53.66 \%$ ) on the cathode. The result was probably caused by the redox reaction, namely the shedding of the coating on the anode electrode's surface, and reactions around the cathode electrode's surface.
\end{abstract}

Keywords: remote sensing, satellite images, lakes, oligotrophy

\section{Introduction}

As a new type of electrochemical processing, electrochemical technology has recently been paid more and more attention in the wastewater treatment field due to its advantages of larger specific surface area, better transfer effect, higher current efficiency, and space-time yield [1-3]. Electrochemical treatment of wastewater is a

*e-mail: wanghao1689@gmail.com relatively new type of wastewater treatment technology that is gradually developing into a promising technology [4-5]. Meanwhile, it has been successfully applied in the purification of wastewater from dye production [6] and from textile wastewater containing cyanides [7], phenols [8-9], and domestic sewage [10].

Coking wastewater is generated from coal coking, coal gas purification, and by-product recovery processes of coking [11-14]. It contains complex inorganic and organic pollutants such as ammonium, sulfate, cyanide, thiocyanate, phenolic compounds, polynuclear aromatic hydrocarbons, and polycyclic nitrogen-containing acyclic compounds, 
etc. [15-17]. Meanwhile, most academic studies have focused on the reaction mechanism and determining the reaction intermediate for the electrochemical method, and further studies on the influence of various factors for experimental effect also were deeply investigated [1822].

Besides, in order to get better removal efficiency, $\mathrm{RuO}_{2}$ and $\mathrm{IrO}_{2}$ coated with titanium plates were used as anodes of the electrodes device in our experiment. Therefore, coking wastewater was applied in the single factor experiment, and the optimal operating parameters were carried out through the experimental course. Meanwhile, total oxygen carbon (TOC) was analyzed for treatment efficiency from coking wastewater, and effects of various factors could provide the basis for the popularization and application of this technology.

\section{Experimental}

\section{Electrolytic System}

The electrochemical device consisted of the electrolytic cell, electrode plates, and DC power supply. The electrolytic cell was made of synthetic glass, with a dimension of $140 \times 90 \times 130 \mathrm{~mm}$ and an effective volume of $1.3 \mathrm{~L}$. Tests of electrolysis were carried out using an electrolytic device consisting of stainless steel cathode plates and titanium anode plates coated with noble metals, including $\mathrm{Ru}$, Ir, etc. The specification for each plate was $130 \times 65 \times 1 \mathrm{~mm}$. The schematic diagram of the main apparatus is shown in Fig. 1.

\section{Influent Quality}

Wastewater for this study was fed from a secondary sedimentation tank in a coking plant in Tangshan. The composition of the coking wastewater used in all experiments is shown in Table 1.

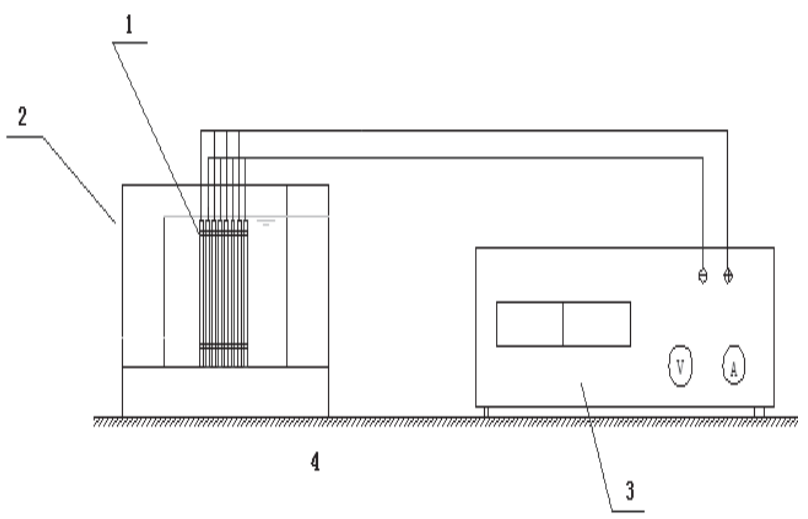

Fig. 1. Schematic diagram of the experimental apparatus: 1 . electrode plates, 2. electrolytic cell, 3 . electric power source, 4 . experiment table.
Table 1. Raw water quality and recycled water indexes.

\begin{tabular}{|c|c|c|c|}
\hline Parameter & TOC $(\mathrm{mg} / \mathrm{L})$ & $\begin{array}{c}\text { Chroma } \\
(\mathrm{mg} / \mathrm{L})\end{array}$ & $\mathrm{pH}$ \\
\hline Concentration & $182.3 \sim 230.9$ & $100.2 \sim 136.5$ & $5.9 \sim 6.7$ \\
\hline
\end{tabular}

\section{Results and Discussion}

\section{Influence of Electrolytic Time}

As is shown in Fig. 2, the removal rate of TOC kept rapid growth with the length of electrolytic time in the first $60 \mathrm{~min}$ and became flat in the last $40 \mathrm{~min}$. And organic compounds could be obviously degraded from the wastewater. However, there was little function to the treatment when prolonging reaction time after $60 \mathrm{~min}$. Thus the optimal electrolysis time was $60 \mathrm{~min}$.

\section{Influence of Electrolytic Current}

As seen in Fig. 3, the removal rates of TOC could reach $73 \%$ when electrolysis current was $8 \mathrm{~A}$, while it increased quickly with the current density. However, the removal rates of TOC decreased if the current exceeded 8 $\mathrm{A}$, and wastewater temperature rose quickly. Meanwhile, reaction driving-power and electric energy consumption increased with the TOC removal rate. But there were removal and energy input requirement extreme for pollutants in the electrochemical system. Besides, because the input energy achieved the extreme circumstance, there was a higher removal efficiency and better redox reaction with the input energy increasing. On the contrary, with the decreasing of input energy, adverse reactions happened and the current efficiency decreased instead of increasing removal efficiency. Therefore, the proper current of the experiment was $8 \mathrm{~A}$.

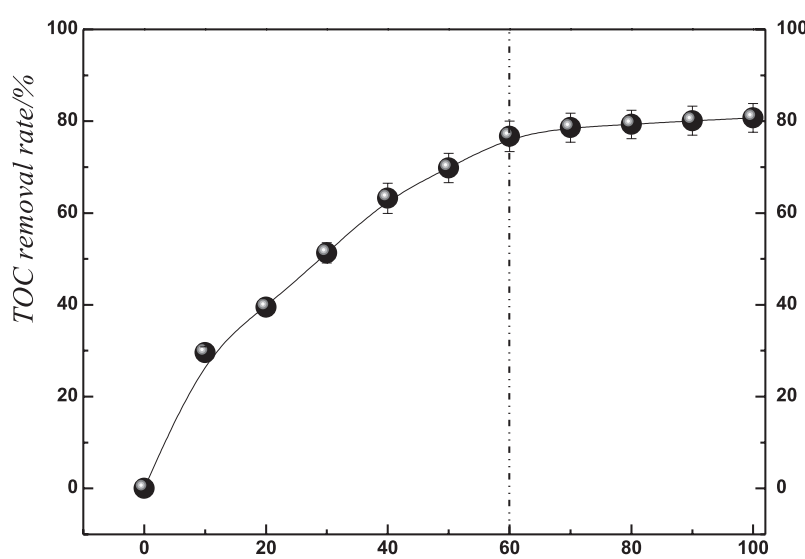

Fig. 2. Influence of electrolytic time on TOC removal rate (when current density is $8 \mathrm{~A}$ and electrode span $1 \mathrm{~cm}$; percentages of TOC removal are shown as the means \pm s.d., $n=3$ ). 


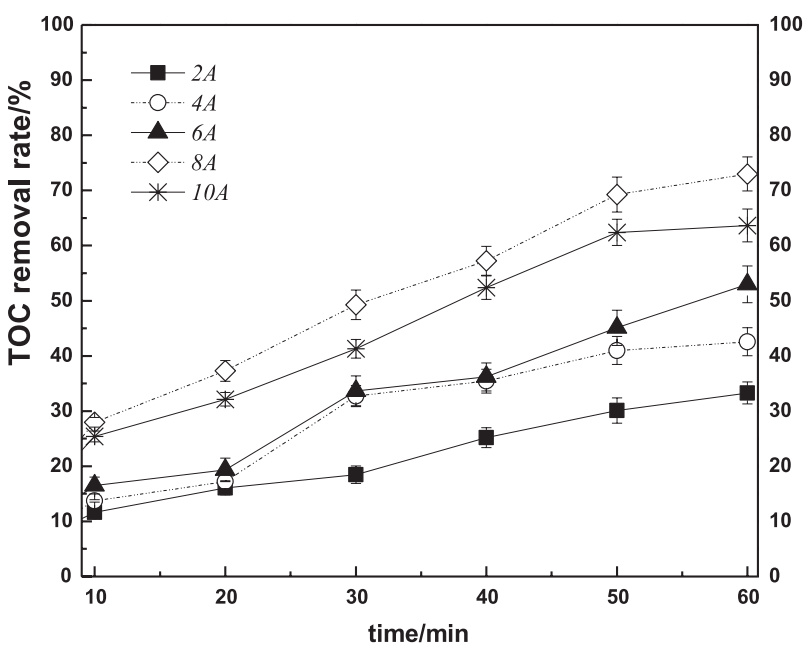

Fig. 3. The influence of electrolytic current on TOC removal rate (when electrolysis time was $60 \mathrm{~min}$ and plate spacing 1 $\mathrm{cm}$; percentages of TOC removal are shown as the means \pm s.d., $\mathrm{n}=3$ ).

\section{Influence of Electrode Span}

As seen in Fig. 4, the treatment effect of TOC reached a maximum of about $67 \%$ when plate spacing was $1 \mathrm{~cm}$, while the removal rates of TOC were obviously influenced by it. The smaller the plates spacing, the larger the current on the electrode. And the concentrations of $\mathrm{H}_{2} \mathrm{O}_{2}$ and -OH were higher, which influenced the degradation of organic matter. When the plate spacing become too small, the current on the electrode decreased rapidly as the generation of spark in the reaction process increased with electrode resistance, and then electrolysis was reduced. Meanwhile, when plate spacing increased, there would be higher system resistance that resulted in a decrease in removal rates. As an influence on the removal of TOC with

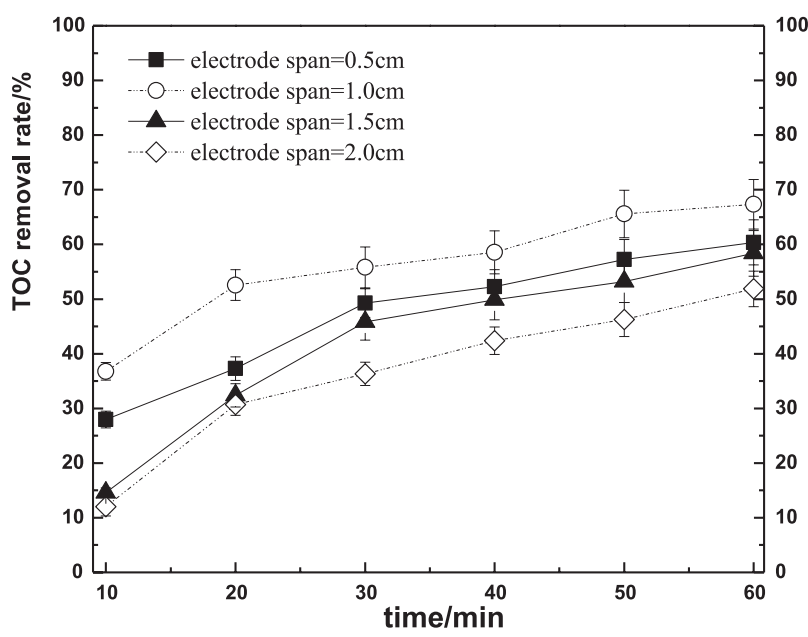

Fig. 4. Influence of electrode span on TOC removal rate (when electrolysis time is $60 \mathrm{~min}$ and current density $8 \mathrm{~A}$; percentages of TOC removal are shown as the means \pm s.d., $n=3$ ). current density, the reasons came down to whether input energy was extreme energy. Besides, Fig. 4 indicated that the input power was approaching extreme power mostly when plate spacing was $1 \mathrm{~cm}$.

\section{Anode Morphology Characteristic and Component Analysis}

As seen in Figs 5 and 6, electrode coating exhibited favorable physical characteristics before use, but some cracks still existed on its surface. After use, fair-sized depletions and coating cracks began to appear on its surface, which was the reason why electrode removal effectiveness decreased. Meanwhile, nascent oxygen was generated during electrolysis, but some cracks appeared on the active coatings, so part of the oxygen may penetrate into the titanium substrate surface by diffusion or migration patterns, and then generate a nonconductive $\mathrm{TiO}_{2}$ with titanium and produce the reverse $\mathrm{PN}$ junction conductance, while electrolysis liquid through the cracks may also invade the titanium base. There would be a titanium oxide matrix to appear, which caused titanium substrate with an active coating interface and exfoliation corrosion. Meanwhile, this made electrode

a)

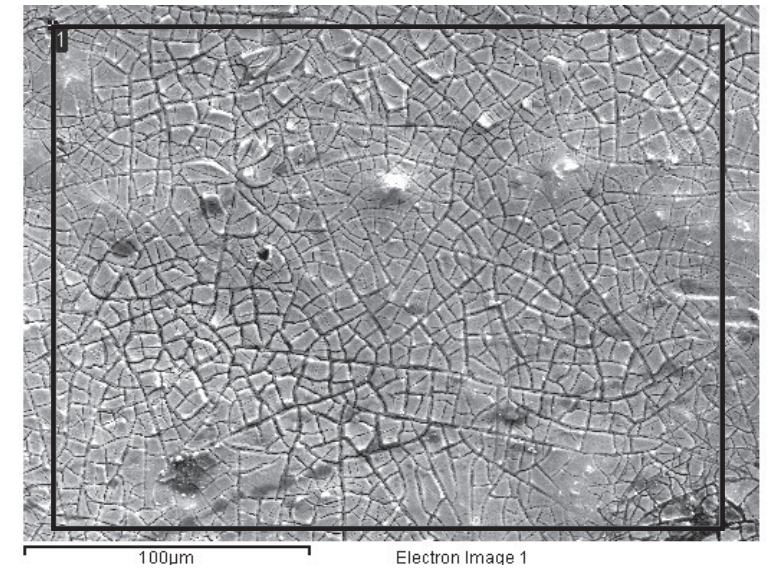

b)

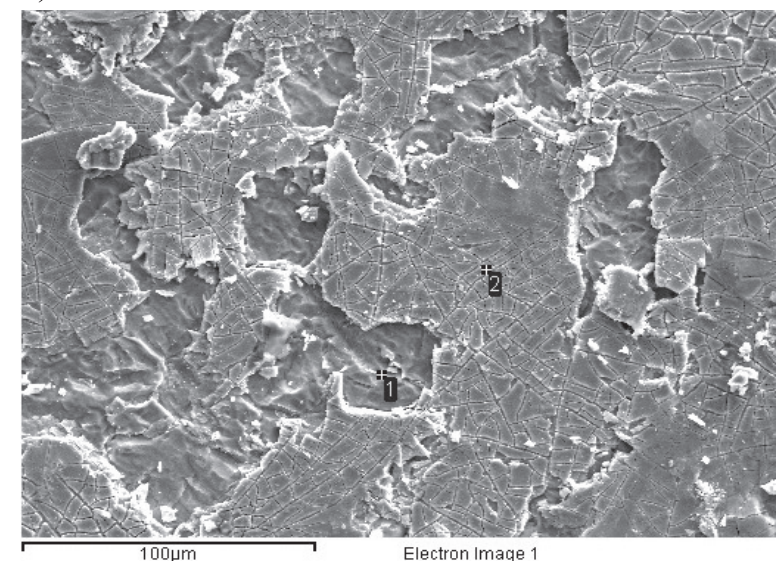

Fig. 5. $\mathrm{Ti} / \mathrm{RuO}_{2} \cdot \mathrm{IrO}_{2}$ morphology characterization of anodic coating: a) before use, b) after use. 
a)

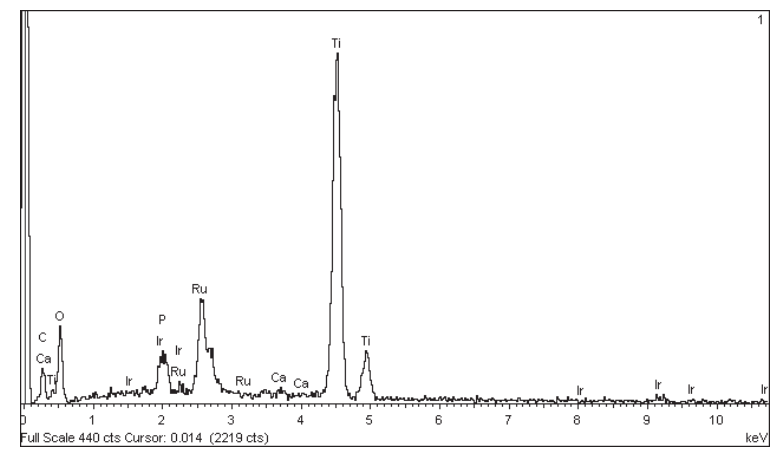

b)

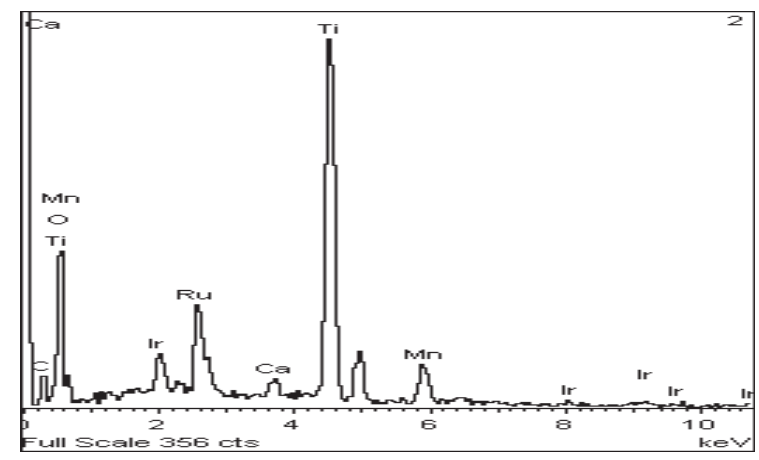

Fig. 6. Anode EDS maps: a) before use, b) after use.

potential increase, and electrode potential rose further and promoted the dissolution of the coating and titanium substrate oxidation; this severe circle would eventually lead to electrode failure.

In addition, $\mathrm{Ti}$ content in surface coating could achieved $92.69 \%$ after use, which indicated that the coatings almost peeled off completely, and one point on the titanium-based surface in Fig. 5b) could approve it. Meanwhile, when the coatings peeled off to a certain degree, the passivation would not carry out. Besides, $\mathrm{Ca}$ content in coating increased with a small quantity, which indicated that no serious calcium anode fouling occurred on the electrode. However, higher Mn content appeared on used anode surface, and it was relatively high. Meanwhile, because there was some heavy metal content in the coal, the coking wastewater often contained considerable metal ions, and these metal ions formed organometallic complexes with phenols in wastewater and organic vehicles. These complexes were poisonous and deemed to be the "three-induced" effect on nature, which had important environmental significance. Meanwhile, heavy metals were found to have a plentiful presence in coking wastewater, and the average $\mathrm{Mn}$ content (10 samples) was about $3.0 \mathrm{mg} / \mathrm{l}$ at low temperature, compared with $1.75 \mathrm{mg} / \mathrm{l}$ at high temperature. Besides, $\mathrm{Mn}$, as a medium, could play an important role in dielectric oxide, and Mn ions exhibited a beneficial effect for the presence of oxidation. However, Ru content decreased, indicating that $\mathrm{Ru}$ dissolution occurred, and when the anode potential was more positive than $1.387 \mathrm{~V}$ vs. SHE, then $\mathrm{RuO}_{2}$ was oxidized to $\mathrm{RuO}_{4}$ :

$$
\mathrm{RuO}_{2}+2 \mathrm{H}_{2} \mathrm{O} \rightarrow \mathrm{RuO}_{4}+4 \mathrm{H}^{+}+4 e
$$

or:

$$
\mathrm{Ru}+4 \mathrm{H}_{2} \mathrm{O} \rightarrow \mathrm{RuO}_{4}+8 \mathrm{H}^{+}+8 e
$$

$\mathrm{RuO}_{2}$ might form $\mathrm{RuO}_{4}$ in solution, and then $\mathrm{RuO}_{4}$ could be decomposed:

$$
\mathrm{RuO}_{4}+x \mathrm{H}_{2} \mathrm{O} \rightarrow \mathrm{RuO}_{2} \bullet x \mathrm{H}_{2} \mathrm{O}+\mathrm{O}_{2}
$$

As shown in above, the black precipitates could be considered $\mathrm{RuO}_{2} \cdot \mathrm{xH}_{2} \mathrm{O}$, which would be deposited on the electrode surface.

Under conditions of the alkaline environment, $\mathrm{RuO}_{2}$ was oxidized to $\mathrm{RuO}_{4}$, but $\mathrm{OH}^{-}$could discharge and produce oxygen under low potential, thereby inhibiting oxidation of catalytic activity in coatings. Compared with acid environment, the operating life of coatings would be long enough for 5 6 times. In addition, acid solution contained chloridion, as $\mathrm{Ru}$ and $\mathrm{Cl}^{-}$would combine under different valence states, and soluble $\mathrm{RuCl}^{-(\mathrm{n}-\mathrm{m})}$ (chloride complex ions) would be generated. Chloridion concentration was relatively high in coking wastewater, and anode existed oxygen evolution reaction, thus obvious dissolution occurring in anode coatings would be reasonable. Meanwhile, the electrode would be not worked when the anode surface catalysis coatings dissolved to an extent.

As seen in Tables 2 and 3, Ir content was minor in coatings, which induced the chlorine evolution potential and oxygen evolution potential that were not high, and the difference was small. Meanwhile, increasing Ir content could raise the oxygen evolution potential, which could enhance the chlorine evolution efficiency to lessen the coatings depletion.

\section{Cathode Morphology Characteristic and Component Analysis}

As seen in Fig. 7, crack morphology of the cathode surface could be in favor of hydrogen escape along with

Table 2. $\mathrm{Ti} / \mathrm{RuO}_{2} \cdot \mathrm{IrO}_{2}$ anode electrode coating composition (before use).

\begin{tabular}{|c|c|c|}
\hline Element & Weight $\%$ & Atomic\% \\
\hline $\mathrm{C} \mathrm{K}$ & 6.43 & 14.34 \\
\hline $\mathrm{O} \mathrm{K}$ & 35.21 & 58.96 \\
\hline $\mathrm{P} \mathrm{K}$ & 0.07 & 0.06 \\
\hline $\mathrm{Ca} \mathrm{K}$ & 0.58 & 0.39 \\
\hline $\mathrm{Ti} \mathrm{K}$ & 39.66 & 22.18 \\
\hline $\mathrm{Ru} \mathrm{L}$ & 12.37 & 3.28 \\
\hline $\mathrm{Ir} \mathrm{M}$ & 5.69 & 0.79 \\
\hline
\end{tabular}


Table 3. Ti/ $\mathrm{RuO}_{2} \cdot \mathrm{IrO}_{2}$ anode electrode coating composition (after use).

\begin{tabular}{|c|c|c|c|c|c|c|c|c|c|}
\hline Spectrum & In stats. & $\mathrm{C}$ & $\mathrm{O}$ & $\mathrm{Ca}$ & $\mathrm{Ti}$ & $\mathrm{Mn}$ & $\mathrm{Ru}$ & $\mathrm{Ir}$ & Total \\
\hline 1 & Yes & 7.31 & & & 92.69 & & & & 100.00 \\
\hline 2 & Yes & 4.98 & 44.91 & 1.02 & 30.50 & 4.76 & 9.42 & 4.42 & 100.00 \\
\hline Max. & & 7.31 & 44.91 & 1.02 & 92.69 & 4.76 & 9.42 & 4.42 & \\
\hline Min. & & 4.98 & 44.91 & 1.02 & 30.50 & 4.76 & 9.42 & 4.42 & \\
\hline
\end{tabular}

the cracked gaps, which could make for decreasing the Ohm drop and operating voltage in electrochemical reaction. Meanwhile, there was a bubble effect in the electrochemical reaction, and its influence could be expressed by two factors because: 1) the bubbles grew and adhered to the interface of the electrode and electrolyte, a bubble curtain was formed, which made the electrode active area decrease and allowed the electrode surface potential and current density to achieve microcosmic maldistribution and 2) the bubbles dispersed in solution, which made the electrolyte become a gas-liquid mixed system, resulting in real conductivity decreasing.

a)

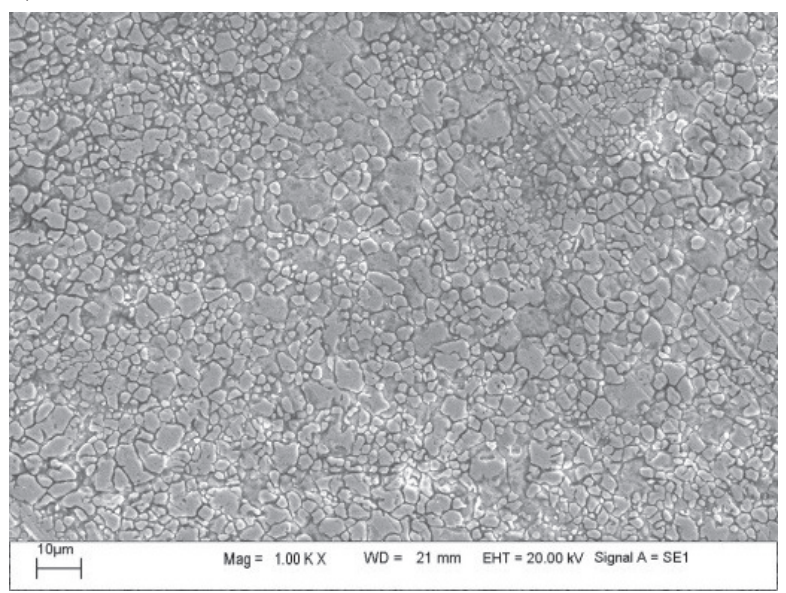

b)

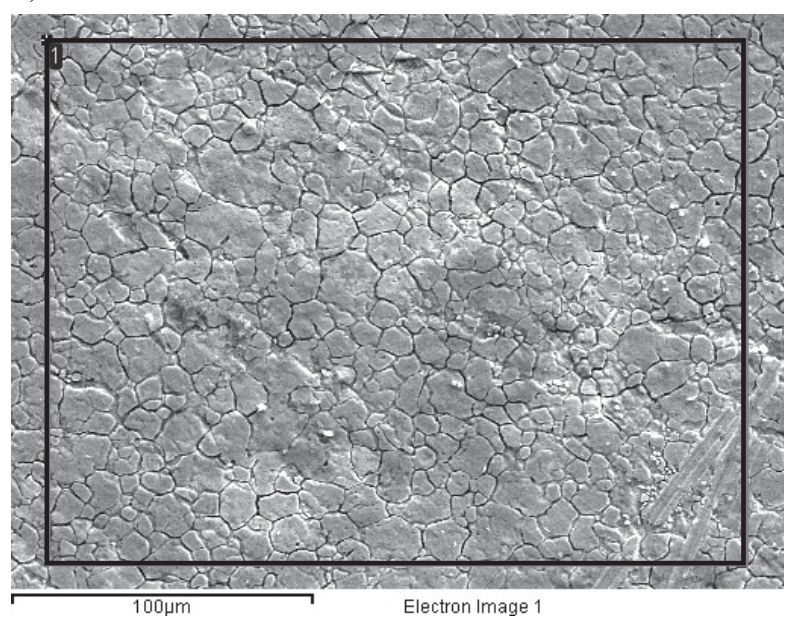

Fig. 7. Morphology characterization of cathode: a) before use, b) after use.
Meanwhile, Ohm drop and operating voltage increased and the energy consumption of the system was enhanced.

As seen in Fig. 8 and Tables 4 and 5, cathode electrode surface exhibited cracked characteristics to some extent before use, but it was not obvious, which may be owing to its manufacturing process. And it would not influence its electrochemical characteristics. Through the experiments, the change of cathode electrode surface morphology occurred, and the cracks gradually increased, which was owing to the redox reaction in the cathode electrode. In addition, the component of the cathode exhibited an obvious difference before and after use. Namely, Fe content decreased obviously, which could be considered as its consumption during redox reaction. Besides, quite a few fouling on the cathode electrode surface appeared after use, which would be formed with $\mathrm{MgCO}_{3}$ and $\mathrm{CaCO}_{3}$ in large measure. Therefore, the descaling should be paid close attention during practical application.

a)

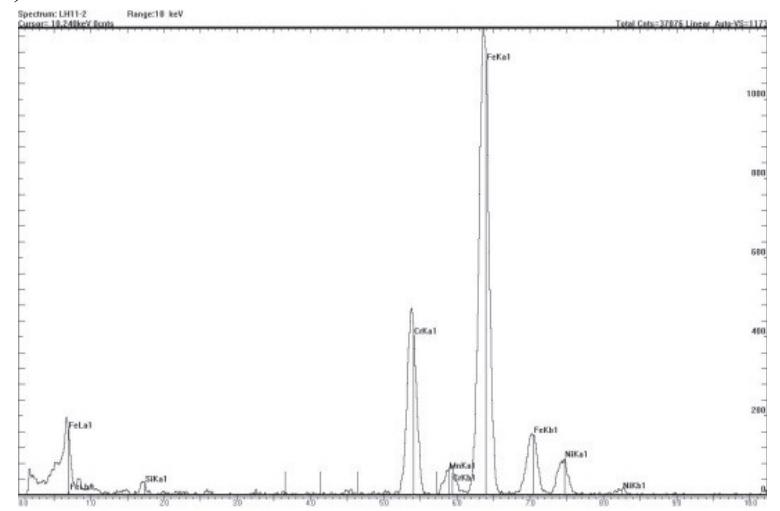

b)

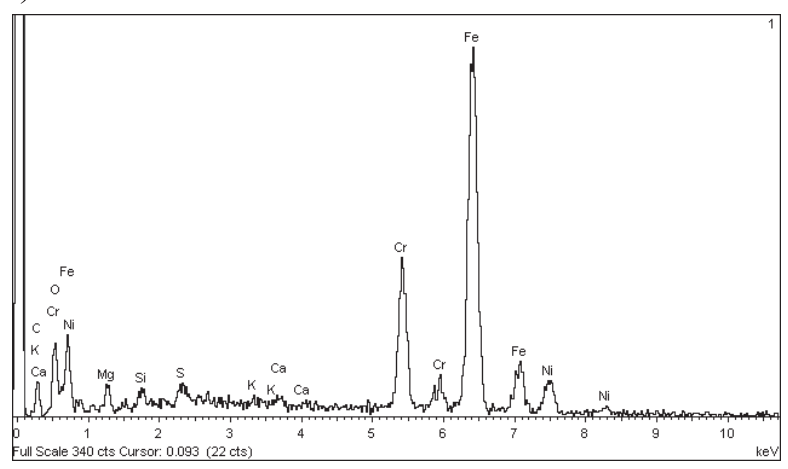

Fig. 8. Cathode EDS map: a) before use, b) after use. 
Table 4. Cathode surface composition (before use).

\begin{tabular}{|c|c|c|c|c|c|c|}
\hline Element & Line & Weight $\%$ & Error & K-Ratio & Cnts/s & Atomic\% \\
\hline $\mathrm{Si}$ & $\mathrm{Ka}$ & 0.77 & 0.044 & 0.0039 & 6.00 & 1.51 \\
\hline $\mathrm{Cr}$ & $\mathrm{Ka}$ & 17.13 & 0.20 & 0.19 & 138.09 & 18.11 \\
\hline $\mathrm{S}$ & $\mathrm{Ka}$ & 0.74 & 0.049 & 0.0074 & 4.54 & 0.74 \\
\hline $\mathrm{Fe}$ & $\mathrm{Ka}$ & 72.57 & 0.53 & 0.71 & 375.04 & 71.42 \\
\hline $\mathrm{Ni}$ & $\mathrm{Ka}$ & 8.80 & 0.23 & 0.078 & 30.24 & 8.23 \\
\hline
\end{tabular}

Table 5. Cathode surface composition (after use).

\begin{tabular}{|c|c|c|}
\hline Element & Weight $\%$ & Atomic $\%$ \\
\hline $\mathrm{C} \mathrm{K}$ & 13.31 & 35.76 \\
\hline $\mathrm{O} \mathrm{K}$ & 7.90 & 15.93 \\
\hline $\mathrm{Mg} \mathrm{K}$ & 2.02 & 2.68 \\
\hline $\mathrm{Si} \mathrm{K}$ & 0.79 & 0.91 \\
\hline $\mathrm{S} \mathrm{K}$ & 0.69 & 0.69 \\
\hline $\mathrm{K} \mathrm{K}$ & 0.21 & 0.17 \\
\hline $\mathrm{Ca} \mathrm{K}$ & 0.47 & 0.38 \\
\hline $\mathrm{Cr} \mathrm{K}$ & 13.41 & 8.33 \\
\hline $\mathrm{Fe} \mathrm{K}$ & 53.66 & 31.01 \\
\hline $\mathrm{Ni} \mathrm{K}$ & 7.54 & 4.15 \\
\hline
\end{tabular}

\section{Conclusions}

In the experiments, we determined the operating optimum technological conditions using quite a few testing factors. The optimal parameters could be obtained for electrolysis time $60 \mathrm{~min}$, current density $8 \mathrm{~A}$, and electrode span $1 \mathrm{~cm}$. This system could remove more than $73 \%$ of total organic carbon under optimum conditions. Through small pilot-scale continuous experiments and a scanning electron microscope, obvious change of element components on the electrodes surface were analyzed, especially $\mathrm{Ti}$ content on the anode and $\mathrm{Fe}$ content on the cathode. From the aforementioned analysis, the electrochemical method could work well in coking wastewater advanced treatment to remove organic compounds, which is difficult to be biodegraded.

\section{Acknowledgements}

Financial support for this research by the Youth Foundation of the Hebei Educational Committee (QN2015197), and for a Hebei Province science and technology project (15273601D) and Tangshan science and technology project (13130203b) are gratefully acknowledged.

\section{References}

1. OZYONARF., KARAGOZOGLU B. Operating cost analysis and treatment of domestic wastewater by electrocoagulation using aluminum electrodes [J]. Pol. J. Environ. Stud. 20 (1), 173, 2011

2. HAI T., SHA J.P., LIU G.Z., OU Y.L. Advanced treatment of biologically pretreated coking wastewater by electrocoagulation degradation behavior and mechanism. Pol. J. Environ. Stud. 24 (3), 1355, 2015.

3. ULUCAN K., KURT U. Comparative study of electrochemical wastewater treatment processes for bilge water as oily wastewater: A kinetic approach. J. Electroanal. Chem. 747, 104, 2015.

4. DUAN F., LI Y., CAO H., WANG Y., CRITTENDEN J.C., ZHANG Y. Activated carbon electrodes: electrochemical oxidation coupled with desalination for wastewater treatment. Chemosphere. 125, 205, 2015.

5. WANG H., CHEN L., YOU Z.G., YANG Y., ZHANG L. Removal of residual organics in coking waste-water under different electrolytic conditions using three-dimensional system. Fresen. Environ. Bull. 22 (2), 395, 2013.

6. SHEN Z.M., WU D., YANG J. Methods to improve electrochemical treatment effect of dye wastewater. J. Hazard. Mater. 131 (1), 90, 2006.

7. ARELLANO C.A.P., MARTINEZ S.S. Indirect electrochemical oxidation of cyanide by hydrogen peroxide generated at a carbon cathode. Int. J. Hydrogen. Energ. 32, 3163, 2007.

8. CUI Y.P., YANG C.Z., QIAN G.M. Remediation of phenolcontaminated sediment by non-uniform electrochemical oxidation reactor. Fresen. Environ. Bull. 15 (11), 1413, 2006.

9. WU G.M., YUAN S.H., AI Z.H. Degradation of various chlorophenols by electrochemical, electro-fenton, microwave assisted photolytic and microwave assisted photocatalytic methods. Fresen. Environ. Bull. 14 (8), 703, 2005.

10. DAGHRIR R., DROGUI P., TSHIBANGU J. Efficient treatment of domestic wastewater by electrochemical oxidation process using bored doped diamond anode. Sep. Purif. Technol. 131, 79, 2014.

11. WANG J.L., QUAN X.C., WU L.B., WERNER H. Bioaugmentation as a tool to enhance the removal of refractory compound in coke plant wastewater. Process Biochem. 38, 777, 2002.

12. ZHU X., NI J., LAI P. Advanced treatment of biologically pretreated coking wastewater by electrochemical oxidation using boron-doped diamond electrodes. Water Res. 43 (17), 4347, 2009

13. LAI P., ZHAO H.Z., WANG C., NI J.R. Advanced treatment of coking wastewater by coagulation and zero-valent iron processes. J. Hazard. Mater. 147 (1), 232, 2007. 
14. LAI P., ZHAO H. Z., ZENG M., NI J.R. Study on treatment of coking wastewater by biofilm reactors combined with zero-valent iron process. J. Hazard. Mater. 162 (2), 1423, 2009.

15. LIM B.R., HU H.Y., HUANG X., FUJIE K. Effect of seawater on treatment performance and microbial population in a biofilter treating coke-oven wastewater, Process Biochem. 37, 943, 2003.

16. WANG Z.P., HUANG L.Z., SU J. W., LI J., LIU G.H., ZHANG Z. Removal of cyanides in coking wastewater by ferrate pre-oxidization followed by photochemical process. Fresen. Environ. Bull. 17 (8), 1082, 2008.

17. MA Q., QU Y.Y., SHEN W.L., ZHANG Z.J., WANG J.W., LIU Z.Y., LI D.X., Li H.J., Zhou J.T. Bacterial community compositions of coking wastewater treatment plants in steel industry revealed by Illumina high-throughput sequencing. Bioresour. Technol. 179, 436, 2015.

18. LIU Y., XIE J., ONG C.N., VECITIS C.D., ZHOU Z. Electrochemical wastewater treatment with carbon nanotube filters coupled with in situ generated $\mathrm{H}_{2} \mathrm{O}_{2}$. Environ. Sci.: Water Res. Technol. 1 (6), 769, 2015.
19. TU X., XIAO S., SONG Y., ZHANG D., ZENG P. Treatment of simulated berberine wastewater by electrochemical process with Pt/Ti anode. Environ. Earth Sci. 73 (9), 4957, 2015.

20. VO K.A., XU X.J., LI T.G., PENG R.H., LIU S.L., YUE X.L. Research on a new electrochemical method combined with chemical coagulation in removal of lead, zinc, and copper from wastewater. Desalin. Water Treat. 57 (33), 15343, 2016

21. MISRA R., GULDHE A., SINGH P., RAWAT I., STENSTRÖM T.A., BUX F. Evaluation of operating conditions for sustainable harvesting of microalgal biomass applying electrochemical method using non sacrificial electrodes. Bioresour. Technol. 176, 1, 2015.

22. SANGEETHA V., SIVAKUMAR V., SUDHAA., KANNAN $\mathrm{K}$. Electrochemical degradation of sago wastewater using $\mathrm{Ti} / \mathrm{PbO}_{2}$ electrode: optimisation using response surface methodology. Int. J. Electrochem. Sci. 10 (2), 1506, 2015. 